\title{
AMT (ACHIEVEMENT MOTIVATIONTRAINING) SEBUAH RANCANGAN INTERVENSI UNTUK MENINGKATKAN EFIKASI DIRI PADA MAHASISWA PROGRAM KHUSUS ULAMA IAIN ANTASARI BANJARMASIN (Studi Eksperimen)
}

\author{
Mulyani, Mubarak dan Yulia Hairina \\ Jurusan Psikologi Islam Fakultas Ushuluddin dan Humaniora IAIN Antasari Banjarmasin \\ Diterima tanggal 20 Pebruari 2014 / Disetujui tanggal 20 Maret 2015
}

\begin{abstract}
Belief or self efficacy is owned by someone to do an action influences activities and efforts of someone in facing difficulty of finishing of certain assignment. Especially, college students who are in Program Khusus Ulama in IAIN Antasari, they need to have a belief with theirselves to finish the final assignment as a schedule decided. With this reason, to increase the self efficacy this study designed an Achievement Motivation Training (AMT). It is a training oriented to increase motivation to achieve some goals had have decided by individuals based on their ability. The research subject invited to know theirselves more through self evaluation based on other people assessment. Then, deciding some goals wants to reach and deciding a strategy and a target based on their ability achieved from result of self evaluation. Sample of this research was 10 people and to decide experiment participation by random sampling. This training was for college students of Program Khusus Ulama of Tafsir Hadis department in Faculty of Ushuluddin and Humaniora. The conclusion is that Achievement Motivation Training (AMT) has effects to increase self efficacy of ollege students of Program Khusus Ulama. The score of Self Efficacy showed that students' self efficacy proven higher than before they follow the AMT.
\end{abstract}

Kata kunci : Achievement MotivationTraining, Efikasi Diri.

\section{Pendahuluan}

IAIN Antasari sebagai salah satu institusi pendidikan tinggi yang menyempurnakan tradisi pendidikan Islam klasik dan modern yang berusaha menjawab kebutuhan masyarakat di Kalimantan Selatan demi kemajuan Islam. Melalui visinya yaitu menjadi pusat pengembangan ilmu-ilmu keislaman multidisipliner yang unggul dan berkarakter, serta misinya yaitu menyelenggarakan pendidikan ilmu-ilmu keislaman, yang memiliki keunggulan dan daya saing internasional, mengembangkan riset ilmu-ilmu keislaman yang relevan dengan kebutuhan masyarakat dan mengembangkan pola pemberdayaan muslim.

Hal ini sesuai dengan tujuannya menyiapkan mahasiswa agar menjadi anggota masyarakat yang memiliki akhlak alkarimah, kemampuan akademik dan/atau professional yang dapat menerapkan, mengembangkan dan/menciptakan ilmu-ilmu keislaman dan seni yang dijiwai oleh nilai-nilai keislaman, serta mengupayakan penggunaannya untuk meningkatkan taraf kehidupan masyarakat dan memperkaya kebudayaan nasional. Oleh karena itu, sebagai salah satu pencapaian tujuan tersebut, maka IAIN Antasari dalam perkembangannya memiliki Program Khusus Ulama (PKU) yang ada di Fakultas Ushuluddin dan Humaniora di jurusan 
Tafsir Hadis yang telah dibuka sejak tahun $2005 .^{1}$

Program khusus ulama dibentuk dengan tujuan untuk mengkaderkan para mahasiswanya menjadi sarjana sekaligus ulama yang professional dan mampu beradaptasi dengan perkembangan zaman, tetap berpegang teguh pada ajaran al-Qur'an dan al-Hadis. Untuk tujuan tersebut, maka Program khusus ulama (PKU) memiliki kurikulum tambahan selain kurikulum regular yang sifatnya menunjang keahlian pada Jurusan Tafsir Hadis yaitu memiliki keterampilan dalam berkomunikasi, membaca dan memahami kitab/buku teks dalam bahasa Arab dan Inggris serta keterampilan keulamaan, dimana pembinaannya dilakukan secara intensif di asrama program khusus ulama, karena sifatnya khusus inilah maka penjaringan dan penyeleksian calon mahasiswanya relatif lebih ketat dan peserta yang diterimanya pun terbatas. Semua berada pada satu arah pencapaian keinginan program sesuai visi, misi dengan tujuan melahirkan sarjana dan sekaligus ulama Ablussunnah wal Jama'ah.

Pelaksanaan program berjalan sebagaimana mestinya dan sesuai progress report tahunan yaitu semacam evaluasi internal berupa pelaporan dari pimpinan fakultas bahwa pelaksanaan program berjalan sesuai dengan apa yang dicanangkan termasuk pembiayaan sudah cukup baik. Hanya saja disisi lain, ada beberapa pengamatan sementara bahwa ternyata program bisa tidak berjalan sebagaimana mestinya yaitu dalam pencapaian target belum sepenuhnya terjangkau. Khususnya terkait dengan masa penyelesaian studi di jurusan ini, misalnya (angkatan 2005), angkatan pertama tidak seluruhnya dapat menyelesaikan studi tepat waktu dan sampai sekarang masih ada yang belum selesai.Begitu juga dengan (angkatan 2006) periode tahun kedua dan seterusnya.

Hal ini ditemukan dalam hasil laporan penelitian yang dilakukan pada tahun $2010^{2}$ tentunya follow-up dari laporan hasil penelitian itu tentunya diharapkan dapat ditemukan pemecahan masalahnya. Asumsinya, banyak hal yang mungkin menjadi penyebab tidak tercapainya target tersebut, misalnya apakah itu karena proses belajar yang tidak menyenangkan, metode yang tidak mampu mengakomodasi setiap keunikan dan perbedaan mahasiswa. Selain itu juga lingkungan pergaulan di kampus yang terkadang tidak seideal yang diharapkan serta bentukbentuk tuntutan sosial yang diterima oleh mahasiswa menjadi salah satu sebab lain dari munculnya tekanan-tekanan kejiwaan, namun tidak hanya itu beban akademis yang terlalu berat, ketidak sesuaian dengan bakat dan minat serta tuntutan lingkungan yang tak terpenuhi terkadang menjadi penyebab juga malah jadi penurunan motivasi para pelajar dalam proses belajarnya. Apabila kondisi menurunnya motivasi tidak segera di atasi, maka keseluruhan proses belajar akan terpengaruh.

Sebelum melakukan penelitian sesungguhnya, peneliti melakukan studi pendahuluan ${ }^{3}$ untuk mendapatkan gambaran secara umum mengenai pelaksanaan pembelajaran di program khusus ulama, yaitu dengan proses wawancara dengan dua orang mahasiswa program khusus ${ }^{4}$ ulama yang mengatakan motivasi mereka mulai mengalami penurunan ketika mulai memasuki semester

${ }^{1}$ Sagir dkk., Evaluasi Pelaksanaan Program Khusus Ulama Tafsir Hadis Fakultas Ushuluddin LAIN Antasari (Kajian Kaderisasi Ulama), Fakultas Ushuluddin. Tidak diterbitkan, h. 35

${ }^{2}$ Sagir dkk. Evaluasi Pelaksanaan Program Khusus Ulama..., h. 40

${ }^{3}$ Studi pendahuluan dilakukan untuk mencari informasi kendala yang dihadapi dalam penyelesaian tugas akhir agar peneliti dapat menemukan dengan tepat intervensi yang perlu dilakukan.

${ }^{4}$ Mahasiswa program khusus ulama angkatan 2009 yaitu $\mathrm{M}$ dan $\mathrm{H}$ (inisial) 
akhir, karena menurut mereka beban (tuntutan tugas) yang dilimpahkan kepada mereka cukup berat. Keyakinan pada diri mereka mengalami penurunan dalam melaksanakan tugas yang diberikan selama perkuliahan dan pada akhirnya cenderung menghindar (prokrastinasi) dari tugas akhir.Hal ini berkaitan dengan konsep efikasi diri yaitu kepercayaan pada kemampuan diri dalam mengatur dan melaksanakan suatu tindakan yang diperlukan dalam rangka pencapaian hasil usaha.Jadi, efikasi diri ini bisa mempengaruhi segi vital kehidupan dalam berkarya dan beraktivitas sehari-hari.

Judge menyatakan bahwa efikasi diri merupakan salah satu core evaluations atau salah satu dasar untuk melakukan evaluasi tentang diri yang berguna untuk memahami diri. ${ }^{5}$ Efikasi diri atau self efficacy merupakan salah satu aspek pengetahuan tentang diri atau knowledge yang paling berpengaruh dalam kehidupan manusia sehari-hari karena efikasi diri yang dimiliki ikut mempengaruhi individu dalam menentukan tindakan apa yang akan dilakukan untuk mencapai suatu tujuan, termasuk di dalamnya perkiraan terhadap tantangan yang akan dihadapi. ${ }^{6}$

Keyakinan yang dimiliki individu untuk melakukan suatu tindakan tersebut mempengaruhi aktivitas serta usaha yang dilakukan individu dalam menghadapi kesulitan penyelesaian tugas tertentu. Keyakinan tersebut akan menggerakkan individu untuk berperilaku lebih tekun, ulet dan berani menghadapi permasalahan. Individu juga akan memiliki motivasi yang lebih kuat untuk mencapai hasil yang maksimal. Keyakinan ini juga akan menentukan jenis perilaku pengatasan seberapa keras usaha yang dilakukan untuk mengatasi permasalahan, serta berapa lama individu mampu bertahan terhadap hambatan yang tidak diinginkan. ${ }^{7}$

Dari gambaran di atas, maka peneliti merancang sebuah bentuk intervensi dalam usaha untuk menindaklajuti penelitian sebelumnya dan sebagai salah satu cara pendekatan psikologis dalam usaha untuk memecahkan masalah yaitu dengan pelatihan. Pelatihan sebagai suatu pengetahuan, kegiatan ini ditujukan untuk membantu individu agar mampu menampilkan perilaku kerja tertentu melalui kegiatan psikologis yang menggunakan prinsip belajar orang dewasa (andragogi). ${ }^{8}$ Kegiatan ini menekankan pada pengalaman setiap individu dalam melakukan setiap kegiatan sebagai sumber belajar utama.Melalui sejumlah pengalaman, peserta diajak merefleksikan diri, sehingga sadar dan termotivasi untuk melakukan perubahan.

Peneliti merancang pelatihan motivasi berprestasi atau AMT (Achievement Motivation Training) yaitu suatu pelatihan yang berorientasi pada peningkatan motivasi untuk mencapai tujuan-tujuan yang telah ditentukan individu berdasarkan kemampuan yang dimilikinya.Dalam AMT ini peserta di ajak untuk lebih mengenal diri melalui evaluasi diri, berdasarkan penilaian orang lain, kemudian menentukan tujuan-tujuan yang ingin dicapai dan menentukan strategi serta target capaian berdasarkan kemampuan diri yang diperoleh dari hasil evaluasi diri.Achievement Motivation Training pada dasarnya merupakan pelatihan yang menggunakan pendekatan belajar melalui pengalaman atau experience learning.

${ }^{5}$ A.T. Locke Judge, A. E., Durham, C.C. \& Kluger , N.A., Dispositional Effect On Job And Life Satisfaction: The Role Of Core Evaluation. Journal of Applied Psychology, Vol.83, No. 1, 1998, h. 17-34. (Dalam Tesis Abdurohim "Gaya Pengambilan Keputusan dalam pembuatan peraturan daerah ditinjau dari self efficacy dan pemaknaan nilai-nilai religiusitas" 2004. Yogyakarta. UGM)

${ }^{6}$ A.T. Locke Judge, A. E., Durham, C.C. \& Kluger, N.A., 1998, Dispositional Effect On Job...h. 17-34.

${ }^{7}$ A. Bandura, Self Efficacy: The Exercise Of Control, (New York: W.H. Freeman And Company, 1997).

${ }^{8}$ M. As’ad, Seri Ilmu Sumber Daya Manusia: Psikologi Industri, (Yogyakarta: Liberty, 2003). 
Beranjak dari latar belakang masalah di atas maka peneliti melangkah pada tahap berikutnya yaitu melakukan penelitian dengan judul: AMT (Achievement Motivation Training): Sebuah Rancangan Intervensi untuk Meningkatkan Efikasi Diri pada Mahasiswa Program Khusus Ulama IAIN Antasari Banjarmasin.

\section{Landasan Teoritis}

1. Efikasi Diri

a. Pengertian Efikasi diri

Manusia selalu berusaha untuk mengontrol peristiwa-peristiwa yang mempengaruhi kehidupannya dan manusia juga tidak dapat mengontrol akan apa yang akan terjadi esok hari. Salah satu mekanisme psikologis yang mampu digunakan untuk memprediksi pencapaian tujuan yang telah ditetapkan oleh seseorang adalah self efficacy.

Self efficacy merupakan sebuah teori yang dapat dimasukkan dalam kelompok social cognitive theory - sebuah kelompok teori yang memiliki peran cukup besar dalam perkembangan teori-teori psikologi sejak pertama kali dikembangkan kurang lebih 20 tahun lalu. ${ }^{9}$ Self efficacy juga menjadi salah satu acuan dalam teori perkembangan anak, namun sekarang menjadi topik yang cukup hangat dan banyak dibahas dalam literatur organisasional. Hal ini disebabkan karena self efficacy seseorang sangat berpengaruh pada kinerja yang dihasilkan seseorang.

Self efficacy merupakan salah satu coreevaluations atau salah satu dasar untuk melakukan evaluasi tentang diri yang berguna untuk memahami diri. Self efficacy merupakan salah satu aspek pengetahuan tentang diri atau self knowledge yang paling berpengaruh dalam kehidupan manusia seharihari karena self efficacy yang dimiliki ikut mempengaruhi individu dalam menentukan tindakan apa yang akan dilakukan untuk mencapai suatu tujuan, termasuk didalamnya perkiraan terhadap tantangan yang akan dihadapi.

Teori Efficacy menjelaskan perubahan-perubahan psikologis dicapai melalui metode dan teknik yang dapat dijelaskan dan diramalkan oleh suatu evaluasi terhadap pengharapan yang dimiliki oleh individu, yaitu self efficacy.Ringkasnya self efficacy didefinisikan sebagai kepercayaan yang dimiliki individu tentang kemampuan atau ketidak mampuan yang dimiliki untuk menunjukkan suatu perilaku atau sekumpulan perilaku tertentu.

b. Aspek-Aspek Efikasi Diri

Self efficacy merupakan unsur kepribadian yang berkembang melalui pengamatanpengamatan individu terhadap akibat-akibat tindakannya dalam situasi tertentu.Persepsi seseorang mengenai dirinya dibentuk selama hidupnya melalui reward and punishment dari orang-orang yang ada disekitarnya. Unsur penguat tersebut (reward and punishment) lama kelamaan akan dihayati sehingga akan terbentuk pengertian serta 
keyakinan mengenai kemampuan dirinya. Corsini ${ }^{10}$ membagi aspek-aspek efikasi diri menjadi empat, yaitu:

1) Aspek Kognisi

Kemampuan seseorang memikirkan cara-cara yang digunakan dan merancang tindakan yang akan di ambil untuk mencapai tujuan yang diharapkan. Agar tujuan tercapai maka setiap orang mempersiapkan diri dengan pemikiran-pemikiran terdepan, sehingga dapat dilakukan tindakan yang tepat. Fungsi utama berpikir memungkinkan seseorang untk memprediksikan kejadian-kejadian sehari-hari yang akan berakibat pada masa depan. Asumsi timbul pada aspek kognisi adalah semakin efektif kemampuan seseorang dalam analisa berpikir dan dalam berlatih mengungkapkan ide-ide atau gagasan pribadi maka akan mendukung seseorang bertindak dengan cepat mencapai tujuan yang diharapkan.

2) Aspek Motivasi

Kemampuan seseorang memotivasi diri melalui pikirannya untuk melakukan suatu tindakan dan keputusan untuk melakukan suatu tindakan dan keputusan untuk mencapai tujuan yang diharapkan.Motivasi seseorang timbul dari pemikiran optimis dalam dirinya untuk mewujudkan tujuan yang diharapkan. Setiap orang berusaha memotivasi diri dengan menetapkan keyakinan pada tindakan yang akan dilakukan dan merencanakan tindakan yang akan direalisasikan. Motivasi dalam efikasi diri digunakan untuk memprediksi kesuksesan dan kegagalan seseorang.

3) Aspek Afeksi

Kemampuan mengatasi perasaan emosi yang timbul pada diri sendiri untuk mencapai tujuan yang diharapkan.Afeksi terjadi secara alami dalam diri seseorang dan berperan dalam menentukan intensitas pengalaman emosional.Afeksi ditujukan dengan mengontrol kecemasan dan perasaan depresif yang menghalangi pola perilaku yang benar untuk mencapai tujuan.

4) Aspek Seleksi

Kemampuan seseorang untuk menyeleksi tingkah laku dan lingkungan yang tepat sehingga dapat mencapai tujuan yang diharapkan.Seleksi tingkahlaku ini dapat mempengaruhi perkembangan personal.Asumsi yang timbul pada aspek ini yaitu ketidakmampuan individual dalam melakukan seleksi tingkahlaku, sehingga membuat perasaan tidak percaya diri, bingung dan mudah menyerah ketika menghadapi situasi yang sulit.

2. AMT (Achievement Motivation Training)

a. Pengertian AMT (Achievement Motivation Training)

AMT ialah salah satu metode peletihan yang digunakan untuk menyemangati individu agar memiliki konsep berprestasi dalam merencanakan langkah untuk meningkatkan prestasi.

Pada tahun 1960, Mc. Clelland memunculkan ide mengenai AMT yang berkonsentrasi pada peningkatkan motif berprestasi, pada saat itu banyak ahli meragukan

${ }^{10}$ R.J. Corsini, Encyclopedia of Psychology, Second Edition. Vol.3, (New York: John Wiley and Son. 1994) 
tentang keberhasilan ide ini, karena pada saat itu banyak para ahli yang sependapat dengan aliran psikoanalisa yang mengatakan bahwa need atau motif itu tertanam sejak masa kanak-kanak awal, sehingga untuk memperkuat atau menanamkan motif berprestasi memerlukan suatu terapi yang lama dan intensif. Mengenai keraguan ini pun hingga saat ini banyak yang menyangsikan apakah dalam waktu sependek itu motif berprestasi dapat meningkat.

Berangkat dari berbagai keberatan dan dukungan yang muncul dari kalangan penganut psikologi belajar dari Amerika yang mempercayai keyakinan terbentuknya motif pada masa lanjut, Mc. Clelland kemudian memutuskan untuk berpandangan ekletik dan sistematik dalam melanjutkan need-ach. Mc Clelland kemudian menggunakan metode yang merupakan dasar dari aliran psikologi belajar.

AMT adalah salah satu jenis training yang sering digunakan untuk berbagai kepentingan yang berkaitan dengan motivasi.Training adalah seperangkat pengalaman belajar yang terencana yang didesain untuk memodifikasi ciri-ciri tertentu perilaku seseorang dengan tujuan mengembangkan keterampilan khusus dan pengetahuan atas sikap tertentu.

Menurut Sikula pelatihan merupakan proses pendidikan jangka pendek yang mempergunakan prosedur yang sistematis dan terorganisir, guna mempelajari pengetahuan dan keterampilan teknis untuk tujuan-tujuan tertentu. Pendapat ini didukung oleh Wexlwy dan Yukl yang menyatakan bahwa pelatihan dan pengembangan adalah istilah-istilah yang menyangkut usaha-usaha berencana yang diselenggarakan agar tercapai penguasaan keterampilan, pengetahuan dan sikap-sikap yang relevan terhadap tugas.

Dari beberapa pengertian di atas maka dapat disimpulkan bahwa Achievement Motivation Training (AMT) adalah pelatihan yang dikemas untuk memotivasi peserta agar menjadi orang yang "berprestasi."Motif berprestasi yang tinggi diketahui ada pada sebagian besar penduduk negara-negara maju dan mandiri. Sementara di negaranegara yang sedang berkembang, motif ini masih rendah.

b. Tujuan AMT (Achievement Training Motivation)

Menurut Mc Clelland dalam bukunya "The Achieving Society" 11 mengemukakan bahwa tujuan AMT itu adalah sebagai berikut:

1) Untuk menentukan sasaran-sasaran yang mengandung tantangan namun realistis guna meningkatkan prestasi individu

2) Untuk mengembangkan dorongan untuk efisiensi dalam melakukan hal-hal secara lebih baik yang akan membantu dalam berproduktivitas

3) Untuk mengendalikan keterampilan-keterampilan yang diperlukan guna menjunjung rencana untuk meningkatkan prestasi

AMT dalam pelaksanaannya dapat dilakukan dengan beberapa metode pelatihan dan pengembangan sekaligus. Dan trade off dari setiap teknik dapat tercapai.

${ }^{11}$ http:/ /www.docstoc.com/docs/22043856/Achievement-Motivation-Training-dalam-Pelatihan-danPengembangan 
c. Komponen-Komponen AMT (Achievement Motivation Training)

Menurut As'ad program pelatihan harus memenuhi komponen-komponen yaitu:

1) Sasaran pelatihan

Setiap pelatihan harus mempunyai sasaran pelatihan yang jelas yang bisa diuraikan ke dalam perilaku yang dapat diamati.Jika sasaran dari pelatihan tidak jelas maka tidak bisa diketahui efektivitas dari pelatihan itu sendiri.

2) Pelatih atau trainer

Tugas pelatih (trainer) adalah mengajarkan bahan-bahan latihan dengan metode tertentu sehingga peseta akan memperoleh pengetahuan, ketrampilan dan sikap yang diperlukan seseorang dengan sasaran yang diinginkan.

3) Bahan-bahan pelatihan

Bahan-bahan Pelatihan Berdasarkan sasaran pelatihan maka dapat disusun bahanbahan pelatihan yang memadai.

4) Peserta

Peserta adalah komponen yang cukup penting. Jika peserta memang memerlukan dan merasa mampu untuk mengikuti program pelatihan, akan dapat mempengaruhi kadar keberhasilan program pelatihan.

\section{Metode Penelitian}

\section{Rancangan Eksperimen}

Dalam penelitian ini menggunakan penelitian eksperimen dan data disajikan dengan pendekatan kuantitatif. Penelitian eksperimen adalah penelitian yang dilakukan dengan secara sengaja oleh peneliti dengan cara memberikan treatment/perlakuan tertentu terhadap subyek penelitian untuk mengetahui bagaimana akibat. ${ }^{12}$ Subyek yang digunakan dalam penelitian ini hanya terdiri dari satu kelompok yaitu kelompok eksperimen.Kelompok eksperimen adalah kelompok yang mendapatkan AMT. Peneliti hanya menggunakan satu kelompok, yaitu kelompok eksperimen dan tidak menggunakan kelompok kontrol karena terkendala kondisi mahasiswa yang tidak berdomisili di Banjarmasin dan sulit mengatur waktunya (ada yang sudah bekerja).

Rancangan eksperimen yang digunakan dalam penelitian ini adalah pre-experiment design. ${ }^{13}$ Rancangan tersebut jika digambarkan dalam tabel, sebagai berikut:

Tabel 1.

Rancangan Eksperimen

\begin{tabular}{|c|c|c|}
\hline Pretest & Perlakuan & Posttes \\
\hline K1 & X & K2 \\
\hline
\end{tabular}

Keterangan:

$\mathrm{K} 1=$ Pengukuran efikasi diri sebelum perlakuan

${ }^{12}$ Latipun, Psikologi Eksperimen, (Malang: UMM Press.Malang, 2006).

${ }^{13}$ F.J. Mc Guigan, Experimental Psychology: Methods of Research. Upper Saddle River, (New York: Prentice-Hall, 1997). 
$\mathrm{K} 2=$ Pengukuran efikasi diri sesudah perlakuan

$\mathrm{X}=\mathrm{AMT}$ (Achievement Training Motivation)

\section{Identifikasi Variabel Penelitian}

Adapun variabel dalam penelitian ini adalah: Variabel bebas yaitu Achievement Motivation Training atau AMT dan variabel tergantungnya adalah Efikasi Diri.

\section{Definisi Operasional}

Adapun definisi variabel dalam penelitian ini adalah:

a) AMT (Achievement Motivation Training) merupakan program yang disusun dalam bentuk pelatihan yang diberikan kepada mahasiswa agar efikasi dirinya mengalami peningkatan. Pelatihan ini dibagi dalam dua pertemuan dengan 6 materi yaitu terkait dengan motivasi berprestasi.

b) Efikasi Diri merupakan keyakinan seseorang akan kemampuan untuk menyelesaikan tugastugasnya, sehingga dapat mempengaruhi dan mengatur fungsi kemampuan individu melalui cara berpikir, memotivasi diri sendiri, merasakan dan proses pengambilan keputusan. Efikasi diri mengandung aspek: kognitif, motivasi, afeksi dan seleksi. Untuk mengukur efikasi diri yang digunakan skala efikasi diri yang disusun oleh Gerrits (2008), berdasarkan teori Corsini ${ }^{14}$ yang kemudian dimodifikasi oleh peneliti. Makin tinggi nilai (skoring) skala yang diperoleh subyek, maka semakin positif efikasi dirinya, demikian juga sebaliknya.

\section{Populasi dan Sampel}

Populasi adalah jumlah dari keseluruhan (satuan/individu) yang karakteristiknya hendak digunakan. ${ }^{15}$ Populasi dalam penelitian ini adalah mahasiswa program khusus ulama Jurusan Tafsir Hadis Fakultas Ushuluddin dan Humaniora IAIN Antasari Banjarmasin yang telah sudah menyelesaikan teori dan sedang proses penyelesaian tugas akhir (skripsi). Sampel adalah sebagian dari populasi yang dianggap mewakili populasinya.Dalam penelitian ini diambil 10 orang sebagai sampel. Untuk menentukan peserta eksperimen dilakukan dengan cara random sampling, yaitu secara acak artinya memeberi peluang yang sama pada setiap anggota populasi ,siapa yang berminat mengikuti eksperimen itulah yang menjadi peserta eksperimen. ${ }^{16}$ Adapun ciri-ciri adalah mahasiswa Jurusan Tafsir Hadis Program Khusus Ulama Fakultas Ushuluddin dan Humaniora IAIN Antasari Banjarmasin yang saat ini masih menjadi mahasiswa aktif, sedang menjalani proses penyelesaian tugas akhir (skripsi) dan bersedia mengikuti AMT selama dua pertemuan.

\section{Metode dan Alat Pengumpulan Data}

Metode pengumpulan data yang digunakan peneliti adalah suatu teknik atau cara-cara yang akan ditempuh oleh peneliti guna mengumpulkan data untuk membuktikan hipotesis dalam tugas penelitian. Pengumpulan data dengan menggunakan alat ukur yaitu skala psikologi.

\footnotetext{
${ }^{14}$ R.J.Corsini, Encyclopedia of Psychology, h. 376.

${ }^{15}$ Supriyanto dan Machfudz, 2010 h. 123.

${ }^{16}$ S. Suryabrata, Metodologi Penelitian, (Jakarta: CV. Rajawali, 1998), h. 57.
} 
Menurut Azwar, ${ }^{17}$ skala psikologi memiliki karakteristik khusus yang berbeda dengan alat pengumpulan data lainnya seperti angket, daftar isian dan lain sebagainya. Beberapa karakteristik skala yang berfungsi sebagai alat ukur psikologis adalah: 1) stimulusnya berupa pertanyaan atau penyataan yang tidak langsung mengungkap atribut yang hendak diukur melainkan mengungkap indikator perilaku dari atribut yang bersangkutan, 2) skala psikologi selalu berisi banyak aitem, 3) respon subyek tidak diklafikasikan dalam benar atau salah namun semua jawaban dapat diterima sepanjang diberikan jawaban yang jujur dan sungguh-sungguh.

Penggunaan metode ini didasarkan pada alasan-alasan bahwa subyek penelitian adalah orang yang paling tahu tentang dirinya sendiri, apa yang dinyatakan subyek dapat dipercaya dan penafsiran dari subyek tentang penyataan di dalam skala yang ditujukan padanya sesuai dengan maksud peneliti. ${ }^{18}$ Metode yang digunakan dalam pengisian skala adalah dengan menggunakan skala atau pernyataan yang diajukan secara tertulis kepada responden dan cara menjawab dilakukan dengan memberikan tanda checklist $(\mathrm{t})$ pada kolom yang telah disediakan.

Skala yang digunakan dalam penelitian ini disusun berdasarkan skala Likert dengan 4 kategori pilihan jawaban.Untuk pilihan jawabannya adalah Sangat Sesuai (SS), Sesuai (S), Tidak Sesuai (TS), Sangat Tidak Sesuai (STS). Semua skala disusun berdasarkan item favorable dan unfavorable yang penilaian atas itemnya adalah sebagai berikut:

Tabel 2.

Skala Pengukuran

\begin{tabular}{|c|l|c|c|}
\hline \multirow{2}{*}{ Ket } & \multirow{2}{*}{ Skor Jawaban } & \multicolumn{2}{|c|}{ Item } \\
\cline { 3 - 4 } & & Favorable & Unfavorable \\
\hline SS & Sangat Sesuai & 4 & 1 \\
\hline S & Sesuai & 3 & 2 \\
\hline IS & I'idak Sesuai & 2 & 3 \\
\hline STS & Sangat Tidak Sesuai & 1 & 4 \\
\hline
\end{tabular}

Skala Efikasi diri yang digunakan di adaptasi dari Gerits ${ }^{19}$ yang telah dimodifikasi oleh peneliti sesuai dengan tujuan penelitian. Adapun skala efikasi diri ini terdiri dari empat aspek, yaitu: Kognitif, motivasi, afeksi dan seleksi.

\section{Validitas dan Reliabilitas}

Validitas didefinisikan sebagai ukuran seberapa cermat suatu alat tes melakukan fungsi ukurnya.Untuk dikatakan valid, tes harus mengukur sesuatu dan melakukannya dengan cermat dan memberikan hasil ukur yang sesuai dengan maksud dilakukan pengukuran tersebut. ${ }^{20}$

Sedangkan reliabilitas alat ukur menunjukkan sejauh mana pengukuran tersebut dapat memberikan hasil relatif sama apabila dilakukan pengukuran terhadap subyek yang sama.

${ }^{17}$ S. Azwar, Reliabilitas dan Validitas, (Yogyakarta: Pustaka Pelajar, 2000) h. 98.

${ }^{18}$ S. Hadi, Metodologi Research, (Yogyakarta: Andi Offset, 1995). h. 187.

${ }^{19}$ Dalam Skripsinya Nugroho, O. A. 2007. Hubungan Antara Self-Efficacy, Penyesuaian Diri Dengan Prestasi Akademik. Mahasiswa. Madiun: Universitas Widya Mandala Madiun. http://lib.atmajaya.ac.id/default.aspx?tabID= 61\&id $=116048 \&$ src $=$ a.

${ }^{20}$ Saifuddin Azwar, Reliabilitas dan Validitas, (Yogyakarta: Liberty1992). 
Reliabilitas disebut sebagai keandalan suatu alat ukur yang diartikan sebagai keajegan (konsisten) dengan alat ukur tersebut. Artinya alat ukur memiliki reliabilitas sempurna apabila hasil pengukuran berkali-kali terhadap subyek yang sama selalu menunjukkan hasil atau nilai yang sama. ${ }^{21}$ Perhitungan validitas dan reliabilitas dengan menggunakan program SPSS for Windows versi 15.0.

\section{Teknik Analisa Data}

Teknik analisa data yang ditetapkan pada penelitian ini adalah metode analisis statistik. Alasannya, bahwa statistik merupakan cara ilmiah yang dipersiapkan untuk mengumpulkan, menyusun, menyajikan dan menganalisa data penelitian yang berwujud angka-angka. Lebih dari itu statistik diharapkan dapat menyediakan dasar-dasar yang dapat dipertanggungjawabkan untuk menarik kesimpulan yang benar dan mengambil keptusan yang baik. ${ }^{22}$ Teknik analisa data yang digunakan untuk menguji hipotesis yang diajukan adalah uji beda dengan t-test.

\section{Pelaksanaan dan Hasil Penelitian}

\section{Alat Pengumpul Data}

Metode pengumpulan data yang digunakan dalam penelitian ini adalah skala psikologi, yaitu skala efikasi diri.Skala efikasi diri ini dimodifikasi oleh peneliti dari skala efikasi dirinya Gerits.Peneliti memodifikasi dengan mengadakan perbaikan dan perubahan pada beberapa item serta dengan pengurangan atau penambahan item. Aspek-aspek efikasi diri mengacu pada aspek kognisi, motivasi, afeksi dan seleksi, yang terdiri dari 50 item. Penyusunan alternatif pada skala ini didasarkan pada skala Likert yang telah dimodifikasi yaitu dengan menghilangkan jawaban ragu-ragu sehingga subyek akan memilih jawaban yang lebih pasti yaitu kea rah yang sesuai ataupun tidak sesuai dengan dirinya. Cara menjawabnya dalam skala ini adalah dengan cara memilih salah satu dari empat alternatif jawaban yang tersedia.

Tabel 3.

Blue Print Skala Efikasi Diri Untuk Uji Coba

\begin{tabular}{|c|l|l|l|c|}
\hline No & \multicolumn{1}{|c|}{ Aspek } & \multicolumn{1}{|c|}{ Favourable } & \multicolumn{1}{c|}{ Unfavourable } & Total \\
\hline 1. & Kognitif & $1,2,14,28,29,41$ & 4,15 & 8 \\
\hline 2. & Motivasi & $3,5,6,7,8,9,24,25,45$ & $10,12,13,33$ & 13 \\
\hline 3. & Afeksi & $18,20,40,42,43,49$ & $16,17,19,30,31$ & 11 \\
\hline 4. & Seleksi & $11,22,23,26,27,37,38,44,47,50$ & $21,32,34,35,36,39,46,48$ & 18 \\
\hline \multicolumn{2}{|c|}{ Total } & 31 & 19 & 50 \\
\hline
\end{tabular}

\section{Perhitungan validitas dan Reliabilitas}

Perhitungan validitas item pada skala efikasi diri menggunakan program SPSS 15 for Windows. Berdasarkan perhitungan validitas item efikasi diri tersebut diperoleh hasil yang valid

${ }^{21}$ Masrun, dkk.1986 dalam penelitian Studi Mengenai Kemandirian pada penduduk di tiga suku bangsa (Jawa, Batak, Bugis). Laporan Penelitian. Kantor Menteri Negara Kependudukan dan Lingkungan Hidup dan Fakultas Psikologi, UGM.Yogyakarta.

${ }^{22}$ S. Hadi, Metodologi Research, h. 30 
sebanyak 39 dari 50 item yang disajikan, maka terdapat item yang gugur sebanyak 11 item. karena nilai probabilitas korelasi [sig. (2-tailed) < dari taraf signifikan (á) sebesar 0,05.

Sedangkan perhitungan reliabilitas $0,889(\mathrm{~N}=30)$. Item-item yang valid diuji reliabilitasnya dengan teknik Maka hasil tersebut menunjukkan bahwa skala itu valid dan reliabel, sehingga dapat digunakan sebagai alat ukur penelitian.

Nomor item yang valid dan yang gugur untuk angket efikasi diri disajikan pada tabel berikut:

Tabel 4.

Blue Print Efikasi Diri Yang Valid dan Yang Gugur

\begin{tabular}{|c|c|c|c|c|c|}
\hline \multirow{3}{*}{ Aspek } & \multicolumn{4}{|c|}{ Nomor dari sifat item } & \multirow{3}{*}{ Total } \\
\hline & \multicolumn{2}{|c|}{ Favourable } & \multicolumn{2}{|c|}{ Unfavourable } & \\
\hline & Sahih & Gugur & Sahih & Gugur & \\
\hline 1.Kognisi & $1,2,14,28,29,41$ & - & 15 & 4 & 8 \\
\hline 2.Motivasi & $3,5,6,7,8,9,24$ & 25,45 & $10,13,33$ & 12 & 13 \\
\hline 3.Afeksi & $20,42,49$ & $18,40,43$ & $\begin{array}{l}16,17,19, \\
30,31\end{array}$ & - & 11 \\
\hline 4.Seleksi & $22,23,26,27,44,47,50$ & $11,37,38$ & $\begin{array}{l}21,34,35, \\
36,39,46, \\
48\end{array}$ & 32 & 18 \\
\hline Total & 23 & 8 & 16 & 3 & 50 \\
\hline
\end{tabular}

\section{Penyusunan Angket Hasil Uji Coba}

Setelah terbukti item yang valid dan gugur, maka dilakukan penomoran kembali item-item pada angket tersebut untuk penelitian. Adapun rinciannya dapat dilihat dari table sebagai berikut:

Tabel 5.

Blue Print Efikasi Diri Untuk Penelitian

\begin{tabular}{|c|c|c|c|}
\hline \multirow{2}{*}{ Aspek } & \multicolumn{2}{|c|}{ Nomor dari sifat item } & \multirow{2}{*}{ Tota } \\
\hline & Favourable & Unfavourable & \\
\hline 1.Kognisi & $1,2,14,28,29,41$ & 15 & 7 \\
\hline 2.Motivasi & $3,5,6,7,8,9,24$ & $10,13,33$ & 10 \\
\hline 3.Afeksi & $20,42,49$ & $16,17,19,30,31$ & 8 \\
\hline 4.Seleksi & $22,23,26,27,44,47,50$ & $21,34,35,36,39,46,48$ & 14 \\
\hline Total & 23 & 16 & 39 \\
\hline
\end{tabular}

\section{Pelaksanaan Penelitian}

\section{Pelaksanaan Eksperimen AMT (Achievement Motivation Training)}

AMT dilaksanakan selama dua hari yaitu tanggal 19 dan 20 September 2013 dari pukul 09.00 sampai dengan 12.30 WITA. Pelatihan ini terdiri dari 6 materi.Masing-masing materi menggunakan metode ceramah, diskusi, dan latihan keterampilan. Pelatihan dilaksanakan di 
gedung Fakultas Ushuluddin dan Humaniora, ruang Munaqasah yang dipandu oleh para trainee dibantu oleh tim peneliti.

Para trainee telah berpengalaman dan terlatih dalam memberikan pelatihan-pelatihan, khususnya pelatihan motivasi. Materi yang disampaikan adalah sebagai berikut: Pentingnya motivasi berprestasi, karakter dari seorang yang berprestasi, membangun impian, mengenali diri,goal setting, analisis SWOT dan net working.

Sebelum AMT dilaksakan, subyek diminta menandatangani surat persetujuan sebelum mengikuti prosedur penelitian ini, sebagai bukti bahwa subyek benar-benar mau mengikuti penelitian ini tanpa dipaksa. Sebelum menyetujui keikutsertaannya dalam penelitian ini, peneliti menjelaskan lebih dahulu mengenai apa yang harus dilakukan.

Prosedur eksperimen pada penelitian ini adalah awal pelatihan peneliti memberikan tes yaitu alat ukur skala efikasi diri, ini sebagai pretest dan diberikan pada semua subyek penelitian. Setelah pengisian skala selesai, diberikan ceramah pengantar yang menerangkan tentang pelatihan motivasi berprestasi (AMT) yang meliputi definisi, manfaat dan materi-materi yang akan diberikan. Dalam ceramah ini juga ditekankan kepada subyek bahwa keseriusan mereka dalam mengikuti metode-metode yang diberikan akan sangat mempengaruhi pemahaman mereka terhadap materi-materi yang diajarkan.

Setelah semua materi AMT diberikan, pada akhir pertemuan trainer kembali menginformasikan bahwa trainer bukanlah pesulap yang bisa menyulap mereka berubah perilakunya, ketika keluar dari ruangan atau pelatihan selesai, tapi kita semua bisa berharap hal-hal yang sudah diajarkan dan dilakukan pada pelatihan ini akan membawa kea rah perubahan yang lebih baik lagi.

Materi dalam AMT secara umum dapat dikelompokkan dalam 4 kelompok dasar yaitu:

a. Achievement Syndrome

Yaitu merupakan pengenalan konsep mengenai apakah yang dimaksud dengan motif dan motivasi berprestasi,setelah mengenali dan memahami apakah yang dimaksud dengan motivasi berprestasi, peserta pelatihan dibiasakan untuk menggunakan pemahaman ini dalam setiap perilakunya dalam pelatihan ini, untuk membiasakan perilaku yang berorientasi pada prestasi. Achievement Syndrome ini telah mencakup ciri motivasi berprestasi yaitu orientasi pada prestasi.

b. Self Study

Melalui materi ini self study ini peserta diberi banyak kesempatan untuk mempelajari diri mereka masing-masing. Peserta harus mengetahui apa yang dibutuhkan oleh diri mereka, apa yang mereka miliki, bagaimana keadaan lingkungan sekitarnya atau dengan kata lain peserta harus dapat memberikan potret diri mereka, dengan mengetahui kekuatan dan kelemahan yang ada pada diri mereka. Materi self study telah tercakup dalam cirri motivasi berprestasi yakni menerima dan menggunakan umpan balik (feedback) dan memperhitungkan resiko.

c. Goal Setting

Goal setting adalah konsep penetapan tujuan yang akan dikenalkan dengan maksud agar peserta merasakan betapa pentingnya penetapan tujuan dalam kehidupan sehari-hari.Untuk lebih mengetahui dan memahami konsep penetapan tujuan, seseorang harus mengenal 
terlebih dahulu dirinya, apa yang menjadi kebutuhannya, mengenal bagaimana lingkungannya.

\section{d. Interpersonal support}

Dalam interpersonal support peserta dianggap sebagai subjek yang dinamis, dapat mempengaruhi dan dapat saling membantu satu dan lainnya. Kontak yang terjdi antar peserta dan pelatih ( trainer) sangat menentukan pematangan proses belajar. Materi interpersonal support secara otomatis akan tercakup dalam keseluruhan aspek manakala peserta melakukan relasi interpersonal, baik dengan peserta lain, fasilitator maupun dengan trainer. Karena di dalam training ini setiap sesi disusun dengan metode metode belajar sedemikian rupa sehingga peserta akan selalu berkesempatan untuk berdinamika secara aktif di dalam kelompok dengan didampingi fasilitator.

Berdasarkan uraian di atas dapat disimpulkan bahwa materi yang terkandung di dalam Achievement Motivation Training terdiri dari empat materi dasar yaitu achivement syndrome, self study, goal setting dan interpersonal support

\section{Tujuan AMT (Achievement Motivation Training) dalam penelitian ini}

Tujuan Achievement Motivation Training Berdasarkan ciri ciri yang mempengaruhi motivasi berprestasi maka tujuan dari AMT (Achievement Motivation Training) adalah :

a. Membantu agar peserta dapat memaksimalkan dan mengarahkan usaha untuk berorintasi pada tujuan yang ingin dicapai.

b. Mendorong peserta agar memiliki tanggung jawab pribadi, khususnya yang berkaitan dengan tanggiung jawab studi mereka di sekolah dan mengenai masa depan mereka pada umumnya

c. Memberi umpan balik kepada peserta yang dapat memacu motivasi peserta untuk berusaha lebih keras dalam menggapai cita-cita dan tujuan

d. Membantu agar peserta lebih mampu memperhitungkan atau mempertimbangkan resiko dari pilihan tindakan yang diambilnya, sehingga peserta dapat memaksimalkan potensi dan usahanya untuk mencapai tujuan yang ingin dicapai.

e. Mendorong peserta untuk memiliki perasan yang kuat dalam menggapai tujuan dan citacitanya

\section{Materi dalam AMT}

Dalam melaksanakan AMT (Achievement Motivation Training) adapun materi yang diberikan diantaranya adalah:

a. Pengenalan

Materi pengenalan ini diantaranya adalah bagaimana peserta mampi mengenal diri dan orang lain, serta dapat mengetahui keistimewaan dirinya.

b. Motivasi Diri

Motivasi dapat disampaikan melalui materi kepada peserta bagaimana mengenal kemampuan diri, menanamkan dorongan positif di dalam diri, membangun dan memelihara motivasi untuk terus meraih prestasi terbaik sesuai dengan usaha yang dilakukan, serta sikap mental terhadap diri sendiri 
c. Pendukung Motivasi

Dalam pelatihan ini juga harus diberikan materi mengenai bagaimana memahami pentingnya bekerja, menemukan dukungan positif dari rekan kerja dan atasan, bagaimana bekerjasama dengan diri sendiri, bagaimana bekerjasama dengan anggota tim untuk meraih prestasi.

d. Hambatan Motivasi

Dalam materi peningkatan motivasi, perlu dilihat pula hal-hal yang mampu menghambuat motivasi diantaranya adalah mengatasi rintangan sulit, menyingkirkan penghalang fisik dan psikologis untuk bekerja, menghadapi kegagalan dan belajar untuk berhasil, dan menghilangkan mental block.

e. Menumbuhkan Motivasi

Adapun hal-hal yang dijadikan sebagai materi pelatihan bagaimana menumbhkan motivasi diantaranya dengan menumbuhkan persepsi "Saya adalah Pribadi Unggul", mampu menghormati diri sendiri dan dapat menerima Perbedaan

f. Goal Setting dan Achievement Planning

Adapun materi dalam pelatihan ini yaitu bagaimana peserta mampu mencapai tujuan yang telah ditetapkan dengan asupan materu pencapaian prestasi kecil demi prestasi kecil dan prestasi bersama

g. Kasus dan Simulasi

Materi dalam AMT dapat diterapkan melalui kasus dan simulasi dengan menerapkan materi cara menumbuhkan motivasi dan bagaimana menjadi motivator bagi diri sendiri dan orang lain

\section{Pelaksanaan Pengumpulan Data}

Pelaksanaan pengumpulan data yang pertama dilakukan pada saat sebelum AMT diberikan (pretest) yaitu pada tanggal 17 September 2013 proses pemberian skala didahului dengan menerangkan tentang tujuan penelitian dan cara petunjuk mengisi skala.Pengumpulan data yang kedua dilakukan pada saat sesudah pelatihan (post tes) yaitu pada tanggal 20 September 2013. Selain skala, subyek juga diminta mengisi angket evaluasi terhadap Kegiatan AMT. Angket evaluasi diberikan kepada subyek setelah selesaimembahas seluruh topik pelatihan. Angket evaluasi yang dilakukan dalam pelatihan ini memiliki beberapa tujuan, diantaranya untuk mengetahui kelebihan dan kekurangan rangkaian penelitian yang telah melibatkan subyek penelitian dari awal hingga akhir.

\section{Pelaksanaan Skoring}

Setelah data terkumpul maka langkah selanjutnya yaitu melakukan skoring atau penilaian untuk keperluan analisa data.Nilai dari item pada angket berkisar 1 sampai 4. Pemberian skor dilakukan berdasarkan jawaban subyek dan sifat item yaitu favourable dan unfavourable. Nilai tertinggi dari masing-masing item adalah 4 dan nilai terendah dari masing-masing item adalah 1, kemudian peneliti menjumlahkan nilai item dari skala yang nilainya digunakan untuk analisis data.

\section{Hasil Olah Data SPSS}

Analisis data yang digunakan dalam penelitian ini adalah dengan menggunakan uji-t yaitu dengan paired samplet- test, yaitu analisis dengan melibatkan pengukuran subyek yang sama 
terhadap suatu pengaruh atau perlakuan tententu dengan bantuan lunak SPSS versi 16. Adapun rangkuman hasil analisis uji-t terlihat di tabel sebagai berikut:

Tabel 6

\section{Rangkuman Hasil Analisis Uji-t}

\begin{tabular}{|l|c|c|}
\hline \multicolumn{1}{|c|}{ Sumber } & T & P \\
\hline $\begin{array}{l}\text { Pre test-Post test peserta } \\
\text { eksperimen }\end{array}$ & $\mathbf{- 6 , 6 6 7}$ & $\mathbf{0 , 0 0}$ \\
\hline
\end{tabular}

Tabel di atas menunjukkan bahwa nilai t adalah sebesar -6,667 dengan sig. 0,00. Hasil perhitungan ini menunjukkan hasil yang signifikan karena $\mathrm{p}<0,05$. Sehingga hipotesisi diterima, dapat ditarik kesimpulan bahwa terdapat perbedaan yang cukup signifikan antara efikasi diri subyek penelitian sebelum dengan sesudah mengikuti AMT.

Dari hasil analisis juga dapat diketahui bahwa nilai rata-rata post-tes subyek penelitian lebih besar daripada nilai rata-rata pre-test. Perhitungan pada tabel menunjukkan bahwa rerata atau mean antara post test dan pre test terlihat menaik walaupun memang tidak terlalu besar. Hal ini dapat dilihat dari nilai mean pretest dan post tes. Adapun hasil mean dapat dilihat dari tabel sebagai berikut:

Tabel 7

Rangkuman Hasil Paired Sample Statistik

\begin{tabular}{|c|l|l|}
\hline Pengukuran & Mean & SD \\
\hline Sebelum ekperimen & 1,0110 & 3,78 \\
\hline Sesudah ekperimen & 1,1660 & 8,40 \\
\hline
\end{tabular}

Temuan data lain hasil penelitian juga menunjukkan skor rata-rata persubyek penelitian mengalami peningkatan pada post test.

Tabel 8

Data Skor Individual Subyek Penelitian

\begin{tabular}{|c|c|c|}
\hline Subyek & Nilai Skor Total Pre-Test & Nilai Skor Total Post-Test \\
\hline 1 & 95 & 110 \\
\hline 2 & 101 & 116 \\
\hline 3 & 103 & 120 \\
\hline 4 & 105 & 132 \\
\hline 5 & 100 & 120 \\
\hline 6 & 103 & 121 \\
\hline 7 & 98 & 104 \\
\hline 8 & 95 & 117 \\
\hline 9 & 100 & 121 \\
\hline 10 & 98 & 105 \\
\hline
\end{tabular}


Terlihat perbedaan tingkat kenaikan skor, yang disebabkan adanya perbedaan menginternalisasi materi pelatihan secara aplikatif dan beragam faktor individual yang menyebabkan terjadinya perbedaan efektivitas dalam pelatihan, misalnya kematangan dan kondisi kesehatan fisik serta psikologis

\section{Pembahasan}

Berdasarkan hasil analisis data statistik yang dilakukan diketahui ada perbedaan skor efikasi diri antara sebelum mengikuti pelatihan dan sesudah mengikuti pelatihan. Hal ini menunjukkan dengan pelatihan atau AMT maka dapat meningkatkan efikasi diri seseorang, dimana efikasi diri awal mulanya merupakan hasil dari proses kognitif yang terjadi pada diri individu. Proses AMT juga banyak mengajarkan individu untuk melakukan evaluasi tentang kemampuan atau kompetensinya untuk mengerjakan tugas, mencapai tujuan, atau mengatasi tantangan. ${ }^{23}$

Pemberian pelatihan motivasi berprestasi (achievement motivation training)akan memunculkan keyakinan jugamemuncul dorongan yang berhubungan dengan prestasi, yaitu menguasai, memanipulasi atau mengorganisir lingkungan sosial maupun fisik, mengatasi rintangan-rintangan yang ada dan memelihara kualitas kerja yang tinggi bersaing dengan ukuran keunggulan muncul dalam diri individu. Ukuran keunggulan ini dapat prestasi sendiri sebelumnya tetapi dapat juga prestasi orang lain. Jadi AMT di sini berupaya memberikan dorongan yang berhubungan dengan pencapaian tujuan, terutama dorongan yang berhubungan dengan prestasi.

Keterampilan dan pengetahuan dalam AMT yang diberikan kepada subyek antara lain materi bagaimana mengenal diri, mengerti tentang persepsi, membuat tujuan dengan mengukur kemampuan yang dimiliki dan bisa mengerjakan pekerjaan sesuai dengan kemampuan dan tugas masing-masing. Semua itu di arahkan pada keyakinan diri atau efikasi dirinya dalam pencapaian tujuan akhir. Harapannya dengan efikasi diri yang tinggi maka keyakinan manusia akan kemampuan dirinya untuk melatih sejumlah ukuran pengendalian terhadap fungsi diri mereka dan kejadian di lingkungannya. Sehingga apabila individu telah merasa yakin dengan kemampuan yang dimilikinya, maka individu dapat menggunakan pengetahuan dan keterampilan yang dimilikinya secara efektif dalam mengatasi situasi yang dihadapinya, khususnya di dalam penelitian ini adalah keyakinan diri dalam penyelesaian tugasnya (skripsi).

Efikasi diri yang tinggi akan mengembangkan kepribadian yang kuat pada seseorang, mengurangi stress dan tidak mudah terpengaruh oleh situasi yang mengancam. Berbeda dengan individu dengan efikasi diri rendah yang akan cenderung tidak mau berusaha atau menyukai kerjasama dalam situasi yang sulit dan tingkat kompleksitas yang tinggi. ${ }^{24}$ Efikasi diri merupakan persepsi individu akan keyakinan kemampuannya melakukan tindakan yang diharapkan. Keyakinan efikasi diri mempengaruhi pilhan tindakan yang akan dilakukan, besarnya usaha dan ketahanan ketika berhadapan dengan hambatan atau kesulitan. Individu dengan efikasi diri tinggi memilih melakukan usaha lebih besar dan pantang menyerah selain itu individu yang mempunyasi efikasi diri tinggi akan mencapai suatu usaha kinerja yang lebih baik karena memiliki

${ }^{23}$ A. Bandura, Self Efficacy: The Exercise Of Control, h. 180.

${ }^{24}$ Lee \& Bobko, dalam Jurnal: Indarti N dan Rostiani R. Kebutuban Akan Prestasi dan Efikasi Diri, Jurnal Ekonomi \& Bisnis Indonesia, Vol.23, No.4, 1994. 
motivasi yang kuat, tujuan yang jelas, keberanian mengambil keputusan bertindak, emosi yang stabil dan kemampuannya untuk sukses.

\section{Keterbatasan dalam Penelitian}

Peneliti menyadari beberapa keterbatasan penelitian yang ada dalam penelitian eksperimen ini antara lain:tidak melakukan screening terlebih dahulu, tidak adanya follow-up hasil AMT kepada subyek penelitian sehingga tidak mengetahui konsistensi dan aplikasi nyata dari efikasi dirinya dalam kesehariannya khususnya dalam penyelesaian tugas akhir (skripsi) serta tidak adanya kelompok kontrol sebagai kelompok pembanding, sehingga hasil penelitian dapat dibandingkan dengan kelompok yang tidak mendapat perlakuan.

\section{Penutup}

Berdasarkan uraian di atas, maka dapat disimpulkan bahwa AMT (Achievement Motivation Training) memiliki pengaruh dalam meningkatkan efikasi diri pada mahasiswa program khusus ulama. Di lihat dari skor efikasi diri terbukti lebih tinggi dibandingkan sebelum mengikuti AMT.

\section{DAFTAR PUSTAKA}

Atkinson, dkk. (1974). Motivation and Achievement, New York: John Wiley \& Sons.

Azwar, S. (2000). Reliabilitas dan Validitas, Yogyakarta: Pustaka Pelajar.

Bandura, A. (1997). Self Efficacy: Toward Unifying Theory of BehavioralChange, Psychological Review, Vol. 84, 1999-215.

Bandura, A. (1997). Self-efficacy: The exercise of control. (1995). Self Efficacy in Changing Society, USA: Cambridge. University Press.

Corsini, R.J, Encyclopedia of Psychology, 2st edition, Vol 3. New York: Jhon Wiley andSsons. 1994. Liufeto, Sonny Edstin. (2012). "Efikasi Diri (Self Efficacy) dan Motivasi Belajar sebagai Prediktor Prestasi Belajar Matematika pada Siswa SMP Negeri 1 Kelas VIII”. Tesis (tidak dipublikasikan).

Hadi, S. (1991). Metodologi Research III, Yogyakarta: Andi Offset.

Hadi, S. (2001). Statistik jilid 2, Yogyakarta. Andi Offset.

Mahtita, Lisa Romanti. (2011). Hubungan Antara Efikasi Diri dengan Motivasi Berprestasi pada Siswa kelas VIII di MTs Sunan Gunung Jati, Selopuro Blitar.

Judge, T A., dkk. (2007, Januari). Self-Efficacy and Work-Related Performance: The Integral Role of Individual Differences. Journal of Applied Psychology. Tahun 2007, vol. 92, No. 1, h. 107-127

Kartono, K. (2003) Kamus Psikologi, Bandung: Pionir Jaya.

Latipun. (2006). Psikologi Eksperimen, Malang: UMM Press.

Mc. Clelland, D. C. (1987). Human Motivation, New York: Cambridge University Press.

Nugroho, O.A. (2007). Hubungan Antara Self-Efficacy, Penyesuaian Diri Dengan Prestasi Akademik Mahasiswa, Skripsi (tidak diterbitkan) Madiun: Universitas Widya Mandala Madiun.

Suryabrata, S. (2008). Metodologi Penelitian, Jakarta: PT. RajaGrafindo Persada. 
Wisanto, Nurmalitasari Indah. (2010) Stress pada siswa SMAN 3 Semarang Ditinjau dari Efikasi Diri Akademik dan Jenis Kelas. Skripsi.

http:/ / lib.atmajaya.ac.id/default.aspx?tabID=61\&id=116048\&src $=a$

http:/ /www.des.emory.edu/mfp/effbook5.html, 